American Journal of Agricultural and Biological Science 3(1): 379-388, 2008

ISSN 1557-4989

(C) 2008 Science Publications

\title{
What Accounts for Growth in African Agriculture
}

\author{
${ }^{1}$ Guy B. Nkamleu, ${ }^{2}$ Kalilou Sylla and ${ }^{3}$ Abdoulaye Zonon \\ ${ }^{1}$ International Institute of Tropical Agriculture (IITA, Ibadan-Nigeria) \\ ${ }^{2}$ University of Cocody-Abidjan, Cote d'Ivoire \\ ${ }^{3}$ University of Ouagadougou, Burkina Faso
}

\begin{abstract}
Empirical relationships between the rates of growth and total factor productivity growth, physical input accumulation, as well as institutional and agro-ecological change is evaluated using an international panel data set on 26 African countries and covering the period 1970-2000. The analysis employs the broader framework provided by empirical growth literature and recent developments in TFP measurement. Results suggest a positive evolution of the total factor productivity during the studied period. This positive performance of the productivity of the agricultural sector was due to positive technological progress rather than technology absorption. However, growth accounting computation highlights the fact that factor accumulation accounts for a large share of agricultural output growth and fertilizer has been the most statistically important physical input contributor to agricultural growth. The study also highlights the extent to which agricultural growth contributors vary across countries and regions in relation with different country conditions, institutions and politicohistorical factors.
\end{abstract}

Key words: Growth accounting, total factor productivity, factor accumulation, capital absorption, africa

\section{INTRODUCTION}

Growth in agriculture, particularly in Africa has been strongly tied to overall economic growth in the literature, given its importance in overall GDP, export earnings and employment, as well as its strong link to non-agricultural growth. As reported by Uma Lele ${ }^{[1]}$, broadly based agricultural production has an enormous impact on the pattern of consumption, saving and investment. This in turn determines internal links between growth in the agricultural and non-agricultural markets and external links between growth in the domestic and international markets. These links govern the pace and robustness of growth. Therefore, agricultural performance is a major focus of the policy agenda in virtually every African country because it directly affects the country's living standards. In particular, looking for strategies that would lead to higher levels of agricultural growth and release a surplus to be used in other sectors is regarded as a key determinant for overall economic growth.

Economic growth is probably one of the most important research topics in modern economics. In recent years, there has been a burgeoning of empirical research into the factors affecting economic growth in both developed and developing countries ${ }^{[2]}$. Most of this research was inspired by the development of endogenous growth theory, which emphasizes the role of technological progress and innovation and human resource development in the growth process ${ }^{[3]}$.

Several theoretical models have been used to explain economic growth. The point of departure for most of these theoretical models is the production function approach pioneered by Solow ${ }^{[4]}$ who specified a neoclassical model of economic growth, where physical capital, labor and an exogenous technology influence the level of output.

The recent literature is centered on why some countries achieve rapid economic growth and some other countries experience stagnation and even economic regression. This has led researchers to examine the main sources of growth for different countries and regions of the world. The focus is on estimating how much growth in output is associated with growth in physical capital and how much is due to total factor productivity (TFP), institutional change and other factors. However, past studies focused on overall economic growth pattern and did not highlight the specificity of the issue for some major sectors. This study improves our understanding by investigating the

Corresponding Author: Guy B. Nkamleu, International Institute of Tropical Agriculture (IITA, Ibadan-Nigeria), c/o LW Lambourn and Co, Carolyn House 26 Dingwall Road, Croydon CR9 3EE, UK 
source of growth in the agricultural sector in Africa. The study applies a growth accounting method to investigate sources of agricultural growth in Africa over the last three decades. The study uses the broader framework provided by the recent empirical growth literature and recent development in TFP measurement to evaluate the relative contribution of main sources of growth in African agriculture.

\section{MATERIALS AND METHODS}

Data and coverage: The analysis is based on data mostly drawn from FAOSTAT (<http://faostat.fao.org >) system of statistics used for the dissemination of statistics compiled by the Food and Agriculture Organization (FAO). Panel data on the top 26 African agricultural producers, from 1970 to 2000 , are analyzed. The 26 countries included in the data set are evenly distributed over all the geographical regions of the continent and are grouped into five regions (Table 1). Our approach involves estimation of aggregate production functions. Data used in the analysis consist of information on agricultural production and conventional and non-conventional inputs. The specific variables used in the study include agricultural production, agricultural labor, number of tractors in use, quantity of fertilizer used, agricultural land and livestock. Specification of output and inputs used is as follows:

\section{- Agricultural output (agricultural production):}

To construct the output series, we followed the methodology suggested in Rao and Coelli, ${ }^{[5]}$. Output aggregated for the year 1990 was used to compute the output series. These 1990 aggregated outputs were computed using international average

Table 1: Summary statistics for data on agricultural sector in the sampled countries

\begin{tabular}{|c|c|c|c|c|c|}
\hline \multicolumn{2}{|l|}{ Region } & \multirow{2}{*}{$\begin{array}{l}\text { Mean (per country } \\
\text { per year) }\end{array}$} & \multirow{2}{*}{$\begin{array}{l}\begin{array}{l}\text { Standard } \\
\text { deviation }\end{array} \\
2,278,355\end{array}$} & \multirow{2}{*}{$\begin{array}{l}\text { Minimum } \\
806,706\end{array}$} & \multirow{2}{*}{$\begin{array}{l}\text { Maximum } \\
11,375,264\end{array}$} \\
\hline Region 1: Northern Africa & $\begin{array}{l}\text { Output (Thousands of 1989-91 } \\
\text { international dollars }\end{array}$ & & & & \\
\hline Algeria & Land $(1,000 \mathrm{ha})$ & 40,143 & 42,042 & 2,445 & 133,898 \\
\hline Egypt & Tractor (Number in use) & 38,422 & 26,055 & 7,980 & 98,157 \\
\hline Morocco & Fertilizer (Metric tons) & 276,783 & 311,845 & 11,629 & $1,259,731$ \\
\hline Sudan & Labor (1,000 persons) & 4,169 & 2,678 & 770 & 8,481 \\
\hline Tunisia & Livestock (Head) & $70,449,418$ & $84,332,779$ & $9,703,200$ & $381,837,000$ \\
\hline Region 2: Western & $\begin{array}{l}\text { Output (Thousands of 1989-91 } \\
\text { international dollars }\end{array}$ & $2,217,974$ & $3,285,861$ & 306,805 & $17,204,508$ \\
\hline Burkina Faso & Land $(1,000 \mathrm{ha})$ & 22,159 & 19,869 & 7,937 & 72,830 \\
\hline Côte d'Ivoire & Tractor (Number in use) & 3,514 & 6,442 & 60 & 30,000 \\
\hline Ghana & Fertilizer (Metric tons) & 42,103 & 78,889 & 157 & 461,000 \\
\hline Guinea (Conakry) & Labor (1,000 persons) & 4,563 & 3,897 & 1,713 & 15,152 \\
\hline Mali & Livestock (Head) & $39,527,878$ & $40,117,236$ & $5,497,000$ & $173,494,024$ \\
\hline \multicolumn{6}{|l|}{ Niger } \\
\hline \multicolumn{6}{|l|}{ Nigeria } \\
\hline \multicolumn{6}{|l|}{ Senegal } \\
\hline \multirow{2}{*}{ Region 3: Central Africa } & Output & $1,339,854$ & 813,049 & 444,913 & $3,212,040$ \\
\hline & Land $(1,000 \mathrm{ha})$ & 34,334 & 19,487 & 8,095 & 57,500 \\
\hline Angola & Tractor (Number in use) & 3,183 & 4,050 & 115 & 10,300 \\
\hline Cameroon & Fertilizer (Metric tons) & 14,362 & 12,757 & 742 & 49,800 \\
\hline Chad & Labor (1,000 persons) & 4,616 & 3,369 & 1,736 & 12,921 \\
\hline Congo DR & Livestock (Head) & $30,244,278$ & $11,815,550$ & $12,201,400$ & $56,565,000$ \\
\hline Region 4: East Africa & Output & $1,925,407$ & $1,023,895$ & 454,660 & $4,025,405$ \\
\hline Burundi & Land (1,000 ha) & 17,878 & 13,890 & 1,485 & 40,000 \\
\hline Kenya & Tractor (Number in use) & 4,098 & 4,009 & 3 & 15,800 \\
\hline Madagascar & Fertilizer (Metric tons) & 24,692 & 41,375 & 100 & 299,900 \\
\hline Rwanda & Labor (1,000 persons) & 5,740 & 3,225 & 1857 & 14,244 \\
\hline Tanzania & Livestock (Head) & $60,355,573$ & $45,624,303$ & $3,418,000$ & $153,143,626$ \\
\hline \multicolumn{6}{|l|}{ Uganda } \\
\hline Region 5: Southern Africa & Output & 975,315 & 224,416 & 542,371 & $1,573,533$ \\
\hline Malawi & Land & 23,717 & 18,208 & 3,180 & 48,235 \\
\hline \multirow[t]{4}{*}{ Mozambique Zimbabwe } & Tractor & 8,274 & 7,243 & 900 & 24,000 \\
\hline & Fertilizer & 67,562 & 63,069 & 1,600 & 185,000 \\
\hline & Labor & 4,051 & 1,548 & 1,906 & 7,591 \\
\hline & Livestock & $22,114,005$ & $18,302,227$ & $5,208,780$ & $55,428,000$ \\
\hline
\end{tabular}

Source: Author calculation 
prices (expressed in US dollars) derived using the Geary-Khamis method ${ }^{[6]}$. The aggregates are based on the sum of price-weighted quantities of different agricultural commodities produced after deduction of quantities used as seed and feed weighted in a similar manner. The resulting aggregates represent disposable production for any use, except as seed and feed. The 1990 output series were then extended to cover the study period, 1970-2000, using the FAO production index number series

- Labor refers to the economically active population in agriculture for each year, in each country. The economically active population in agriculture is defined as all persons engaged or seeking employment in agriculture, forestry, hunting, or fishing sectors, whether as employers, own-account workers, salaried employees, or unpaid workers

- Agricultural land is the sum of the areas under arable land (land under temporary crops, temporary meadows for mowing or pasture, land under market and kitchen gardens and land temporarily fallow), permanent crops (land cultivated with crops that occupy the land for long periods and need not be replanted after each harvest, such as cocoa, coffee and rubber) and permanent pastures (land used permanently for herbaceous forage crops, either cultivated or growing wild)

- Fertilizer: Following other studies ${ }^{[7,8]}$, the sum of nitrogen $(\mathrm{N})$, potassium $\left(\mathrm{P}_{2} \mathrm{O}_{2}\right)$ and phosphate $\left(\mathrm{K}_{2} \mathrm{O}\right)$ expressed in thousands of tons, that are contained in the commercial fertilizers consumed is used as measure of fertilizer input.

- Tractors: We used data on the number of tractors, which refer to total wheel and crawler tractors (excluding garden tractors) used for agricultural production

- Livestock: Following ${ }^{[9]}$, the livestock input variable used in this study is the sheep-equivalent of five categories of animals. The categories of animals considered are buffaloes, cattle, pigs, sheep and goats. Data on the number of these animals are converted into sheep equivalents using the following conversion factors: 8 for buffalo and cattle, and 1 for sheep, goats and pigs

\section{Theoretical framework}

Growth accounting method: The point of departure of our analysis is the neo-classical production function which is written as:

$$
\begin{array}{rl}
\text { In } Q_{i t}=f\left(x_{i t j}, t ; \beta\right)+\varepsilon_{i t} & i=1, \ldots \ldots, n \\
t & =1, \ldots \ldots ., T \\
j & =1, \ldots \ldots ., J
\end{array}
$$

Where $\mathrm{Q}_{\mathrm{it}}$ is output of the $\mathrm{i}$-th country in time period $\mathrm{t}$, $\mathrm{x}_{\mathrm{it}}$ is an $\mathrm{N}^{*} 1$ vector of the logarithm of inputs for the $\mathrm{i}$ th country in time period $t, \beta$ is a vector of unknown parameters and $\varepsilon_{i t}$ is random variable which assumed to be iid $\mathrm{N}\left(0, \sigma_{\varepsilon}^{2}\right)$.

The decomposition of the neo-classical production function to get the residuals is used to break down the growth rate of aggregate output into contribution from the growth of inputs versus productivity change ${ }^{[10,11]}$ :

$$
\dot{\mathrm{Q}}_{\mathrm{it}}=\sum_{\mathrm{j}} \mathrm{a}_{\mathrm{itj}} \dot{\mathrm{x}}_{\mathrm{itj}}+\dot{\mathrm{TFP}}_{\mathrm{it}}
$$

Where dots over variables indicate rate of change $\dot{X}_{t}=\frac{X_{t}-X_{t-1}}{X_{t-1}}$ and $\alpha_{i t j}$ is the output elasticity of input $j$, for country i in time t. $\alpha_{j}=\frac{\partial f(x, t ; \beta)}{\partial x_{j}}$

In our analysis, the aggregate production function in growth rates is given by:

$$
\begin{aligned}
\dot{\mathrm{Q}}_{\mathrm{it}}= & \mathrm{c}+\alpha_{1} \stackrel{\bullet}{\mathrm{Land}}+\alpha_{2} \text { Labor }+\alpha_{3} \text { Fertilizer } \\
& +\alpha 4 \text { Tractor }+\alpha_{5} \mathrm{TFP}+v_{\mathrm{it}}
\end{aligned}
$$

That is:

$$
\begin{aligned}
\left(\begin{array}{l}
\text { Growth rate } \\
\text { of output }
\end{array}\right)-\left(\begin{array}{l}
\text { Growth rate } \\
\text { of FTP }
\end{array}\right)= & c+\alpha_{1}\left(\begin{array}{l}
\text { Growth rate } \\
\text { of land }
\end{array}\right)+\alpha_{2}\left(\begin{array}{l}
\text { Growth rate } \\
\text { of labor }
\end{array}\right) \\
& +\alpha_{3}\left(\begin{array}{l}
\text { Growth rate } \\
\text { of fertilizer }
\end{array}\right)+\alpha 4\left(\begin{array}{l}
\text { Growth rate } \\
\text { of Tractor }
\end{array}\right) \\
& +\alpha_{5}\left(\begin{array}{l}
\text { Growth rate } \\
\text { of livestock }
\end{array}\right)
\end{aligned}
$$

We first compute TFP growth using Data Envelopment Analysis (DEA) procedure (Malmquist indexes). Then, regressing $\dot{\mathrm{Q}}_{\mathrm{it}}-\mathrm{T} \dot{\mathrm{T} P}$ on the growth rate of inputs, using panel data random effect procedure, we obtain coefficients which are interpreted as factor shares. We construct our estimates of contributions to agricultural growth for the period 1970-2000 for our sample of 26 African countries, which allow us to study growth contribution differences within African countries. For the polled and for each group of countries, a separated panel data random effect regression was ran to derive factor share for each of the period (1971-80, 1981-90, 1991-00 and 1971-00). Overall, 28 regressions representing all the categories found in the Table 4-11, were ran. The estimating equation is equation 4 , where the constant accounts for omitted variables (omitted 
Am. J. Agri. \& Biol., 3(1): 379-388, 2008

variables include physical variables such as pesticides as well as less physical factors such as agro-climatic conditions, institutions and political instability...).

Malmquist TFP index approach: Malmquist index methods described in Fare et al. ${ }^{[12]}$, Coelli et al. ${ }^{[13]}$ and Nkamleu $^{[14]}$ are used to measure and analyze total factor productivity, technology and efficiency change in African agriculture. The method calculates total factor productivity indexes using efficiency measures. This approach, when panel data are available, uses DEA-like linear programs and the Malmquist total factor productivity (TFP) index to measure productivity change and to decompose this productivity change into technical change and technical efficiency change.

Following Fare et $a l^{[12]}$, the MI TFP change between the base period $\mathrm{s}$ and a period $\mathrm{t}$ can be written as:

$$
\mathrm{m}_{0}\left(\mathrm{y}_{\mathrm{s}}, \mathrm{x}_{\mathrm{s}}, \mathrm{y}_{\mathrm{t}}, \mathrm{x}_{\mathrm{t}}\right)=\frac{\mathrm{d}_{0}^{\mathrm{t}}\left(\mathrm{y}_{\mathrm{t}}, \mathrm{x}_{\mathrm{t}}\right)}{\mathrm{d}_{0}^{\mathrm{s}}\left(\mathrm{y}_{\mathrm{s}}, \mathrm{x}_{\mathrm{s}}\right)}\left[\frac{\mathrm{d}_{0}^{\mathrm{s}}\left(\mathrm{y}_{\mathrm{t}}, \mathrm{x}_{\mathrm{t}}\right) \mathrm{d}_{0}^{\mathrm{s}}\left(\mathrm{y}_{\mathrm{s}}, \mathrm{x}_{\mathrm{s}}\right)}{\mathrm{d}_{0}^{\mathrm{t}}\left(\mathrm{y}_{\mathrm{t}}, \mathrm{x}_{\mathrm{t}}\right) \mathrm{d}_{0}^{\mathrm{t}}\left(\mathrm{y}_{\mathrm{s}}, \mathrm{x}_{\mathrm{s}}\right)}\right]^{1 / 2}
$$

where the notation $\mathrm{d}_{0}^{\mathrm{s}}\left(\mathrm{y}_{\mathrm{t}}, \mathrm{x}_{\mathrm{t}}\right)$ represents the distance from the period $t$ observation, to the period $s$ technology. A value of ' $\mathrm{m}$ ' greater than one will indicate positive TFP growth from period $\mathrm{s}$ to period $\mathrm{t}$. In (5), the term outside the square brackets measures the Farrell efficiency change between period $s$ and $t$ and the term inside measures technical change, which is the geometric mean of the shift in the technology between the two periods. Thus, the two terms in equation (5) are:

$$
\begin{gathered}
\text { Efficiency change }=\frac{d_{0}^{\mathrm{t}}\left(\mathrm{y}_{\mathrm{t}}, \mathrm{x}_{\mathrm{t}}\right)}{\mathrm{d}_{0}^{\mathrm{s}}\left(\mathrm{y}_{\mathrm{s}}, \mathrm{x}_{\mathrm{s}}\right)} \\
\text { Technical change }=\left[\frac{\mathrm{d}_{0}^{\mathrm{s}}\left(\mathrm{y}_{\mathrm{t}}, \mathrm{x}_{\mathrm{t}}\right) \mathrm{d}_{0}^{\mathrm{s}}\left(\mathrm{y}_{\mathrm{s}}, \mathrm{x}_{\mathrm{s}}\right)}{\mathrm{d}_{0}^{\mathrm{t}}\left(\mathrm{y}_{\mathrm{t}}, \mathrm{x}_{\mathrm{t}}\right) \mathrm{d}_{0}^{\mathrm{t}}\left(\mathrm{y}_{\mathrm{s}}, \mathrm{x}_{\mathrm{s}}\right)}\right]^{1 / 2}
\end{gathered}
$$

The efficiency change component is equivalent to the ratio of the Farrell technical efficiency in period to the Farrell technical efficiency in period $s$, under constant return to scale $\left(\mathrm{EFFCH}_{\mathrm{crs}}\right)$. This efficiency change component can be separated into a scale efficiency and pure technical efficiency change. The pure technical efficiency is obtained by re-computing efficiency change under variable return to scale $\left(\mathrm{EFFCH}_{\mathrm{vrs}}\right)$. The scale efficiency is, therefore, the ratio of efficiency under constant return to scale and the same efficiency under variable return to scale $\left(\mathrm{EFFCH}_{\mathrm{crs}} / \mathrm{EFFCH}_{\mathrm{vrs}}\right)$. The overall index in (5)
Table 2: Mean total factor productivity change and its components by period. African agriculture, 1970-2000

\begin{tabular}{lllll}
\hline & $1971-80$ & $1981-90$ & $1991-00$ & $\begin{array}{l}\text { All (1971- } \\
\text { 2000) }\end{array}$ \\
\hline $\begin{array}{l}\text { Total factor productivity } \\
\text { change (TFPCH) }\end{array}$ & 0.981 & 1.008 & 1.015 & 1.002 \\
$\begin{array}{l}\text { Technical change } \\
\text { (TECHCH) }\end{array}$ & 0.989 & 1.009 & 1.014 & 1.004 \\
$\begin{array}{l}\text { Overall efficiency } \\
\text { change (EFFCH) }\end{array}$ & 0.992 & 1 & 1.001 & 0.998 \\
$\begin{array}{l}\text { Pure efficiency } \\
\text { change (PEFFCH) }\end{array}$ & 1 & 0.996 & 1 & 0.999 \\
$\begin{array}{l}\text { Scale efficiency } \\
\text { change (SEFFCH) }\end{array}$ & 0.992 & 1.003 & 1.001 & 0.999 \\
\hline
\end{tabular}

Source: Geometric means computed from DEA output

Tfpch $=$ Techch $*$ Effch, Effch $=$ Peffch $*$ Seffch

represents the productivity of the production point $\left(\mathrm{y}_{\mathrm{t}}\right.$, $\mathrm{x}_{\mathrm{t}}$ ) relative to the point $\left(\mathrm{y}_{\mathrm{s}}, \mathrm{x}_{\mathrm{s}}\right)$ and a value larger than one depicts positive TFP growth between periods $\mathrm{s}$ and t.

\section{RESULTS AND DISCUSSION}

Sources of TFP growth: Means of the measures of total factor productivity change (TFPCH) are presented in Table 2 for the three last decades. The sample as a whole indicates that the change in total factor productivity of the agricultural sector of the study countries have been positive. Recall that a value greater than unity represents an improvement of TFP, while a value less than the unity represents a decline. On average, total factor productivity has increased by $0.2 \%$ annually. This figure appears to be consistent with some of the recent studies ${ }^{[15,10]}$. However, for some regions, there has been some evidence of productivity regression. It is also important to note that out of the 26 , seven countries (Burkina-Faso, Burundi, Chad, Guinea, Madagascar, Mali and Senegal) have had a negative evolution of the total factor productivity over the period.

Our analysis decomposes TFP into factors that are external/exogenous to the countries (technological change) and factors that are internal/endogenous to the country (its ability to absorb and use the available inputs - efficiency change). We next decompose efficiency change into pure efficiency change and scale efficiency change. The component measures of total factor productivity, overall efficiency change (EFFCH) and technical change (TECHCH), show that there has been technological progress, though for some individual countries there has been some evidence of technological regression. The overall average annual technological change was $0.4 \%$, while a $0.2 \%$ average annual decline of technical efficiency over the studied period was observed. 
Turning to the component measures (pure and scale efficiencies), it appears that both pure and scale technical efficiencies have contributed to the decline of overall efficiency. The various models of new growth theory emphasize human capital as a key factor to drive the long-term growth of income (De Gregorio and Jong-Wha Lee, GDN). To allow differences in the labor quality between countries, previous studies ${ }^{[11]}$ included human capital as an additional input. Benhabib and Spiegel $^{[16]}$ suggest that human capital affects TFP growth through the adoption and implementation of new technologies. Instead of including human capital as an input in production, our approach is such that that human capital accumulation is captured by the efficiency change component of the TFP. The African agricultural sector faces the challenge of acquiring and absorbing foreign technologies. The negative evolution of the efficiency change component suggests that technology absorption is a long-run constraint to the agricultural sector. Table 2 also shows the rates of TFP components, grouped by decade. It appears that, during the 1971-1980 periods the region performed better in raising the efficiency of the agricultural sector. The average growth rate of technical efficiency during that period, although negative, was greater than the average growth rate of technology. The situation was reversed during the 1980s and the 1990s, with better scores in technical change than in technical efficiency change.

Table 3 provides measures of annual changes in EFFCH, TECHCH and TFPCH by different geographical regions. Northern Africa posted the highest TFP growth of $0.8 \%$, mainly due to a technological change growth of $1.1 \%$, followed by Central and Southern Africa. West Africa has posted the lowest rate of $-0.3 \%$. The failure in West Africa was due to a poor efficiency change growth whereas in Eastern Africa, technological change has been the main constraint.

Sources of agricultural growth: Table 4 reports the results of the output growth decomposition by decade, over the entire sample. Agricultural growth performance varies widely over time. Low during the seventies, the average annual growth rate grew to more than $3 \%$ in subsequent decades. The contribution of factor inputs $(98 \%)$ has been on average larger than that of TFP (67\%). Unaccounted factors which might include factors such as agro-climatic shocks, institutions and political instability, also contributed importantly to agricultural output growth (-65\%). The weak performance of the TFP growth was mainly due to its negative evolution during the seventies. In the eighties and nineties, TFP growth rises sharply, while the contribution of factor inputs tended to decline. Busari et al. ${ }^{[17]}$ also found that TFP contribution to total economic growth was negative during the seventies in Africa. In sum, output growth decomposition shows that physical inputs, or factor accumulation globally provides the most important component of output growth during the last three decades.

Narrowing our focus within the contribution of each physical input reveals that output growth due to fertilizer usage is the highest in Africa where it accounts for $51 \%$ of total agricultural output growth, following by the contribution of tractor $(25 \%)$. The amount attributable to labor growth was $21 \%$ while land account only for $4 \%$ of total agricultural growth. The contribution of livestock has been constantly negative. In the time dimension, we observe more stability in the contribution of fertilizer, as well as in the contribution of livestock.

Table 5-9 report results of the output growth decomposition per decade and per geographical group. These results indicate that the strength of the contribution of growth determinants varies across regions, with some common characteristics. The contribution to output growth of TFP is constantly lower than contribution of total inputs. In some regions (North and West Africa), the contribution of TFP is close to the contribution of the physical inputs while in others, factor contribution far exceed TFP contribution.

In all regions, it is apparent that fertilizer is the most important physical input contributor to agricultural growth. Suggesting that fertilizer is a good foundation, on which one can build strong equitable agricultural growth in Africa. Hayami and Ruttan ${ }^{[9]}$ (see for example in p.140) advocated that livestock and land should be seen as proxy for resources endowment and should be included as inputs in aggregated agricultural production function. Most past studies on aggregated

Table 3: Mean total factor productivity change and its components by region. African agriculture, 1970-2000

\begin{tabular}{|c|c|c|c|c|c|c|}
\hline & $\begin{array}{l}\text { Northern } \\
\text { Africa }\end{array}$ & $\begin{array}{l}\text { Western } \\
\text { Africa }\end{array}$ & $\begin{array}{l}\text { Eastern } \\
\text { Africa }\end{array}$ & $\begin{array}{l}\text { Central } \\
\text { Africa }\end{array}$ & $\begin{array}{l}\text { Southern } \\
\text { Africa }\end{array}$ & $\begin{array}{l}\text { All } \\
\text { Africa }\end{array}$ \\
\hline Total factor productivity change (TFPCH) & 1.008 & 0.997 & 1.001 & 1.005 & 1.005 & 1.002 \\
\hline Technical change TECHCH) & 1.011 & 1.002 & 1 & 1.001 & 1.012 & 1.004 \\
\hline Overall efficiency change (EFFCH) & 0.996 & 0.995 & 1.001 & 1.004 & 0.993 & 0.998 \\
\hline Pure efficiency change (PEFFCH) & 0.996 & 0.998 & 1.001 & 1.002 & 0.995 & 0.999 \\
\hline Scale efficiency change (SEFFCH) & 1.001 & 0.996 & 0.999 & 1.001 & 0.998 & 0.999 \\
\hline
\end{tabular}

Source: Geometric means computed from DEA output 
Am. J. Agri. \& Biol., 3(1): 379-388, 2008

Table 4: African agricultural growth decomposition by decade

\begin{tabular}{|c|c|c|c|c|}
\hline & $1971-80$ & $1981-90$ & 1991-00 & All (1971-2000) \\
\hline \multicolumn{5}{|l|}{ Source of growth (annual growth rate in percentage) } \\
\hline Total output growth per year* (a) & 1.43 & 3.03 & 3.53 & 2.71 \\
\hline Total growth due to factor inputs (b) & 1.63 & 1.46 & 3.25 & 2.66 \\
\hline Yearly growth due to Land (c) & -0.19 & 0.16 & 0.11 & 0.11 \\
\hline Yearly growth due to Labor (d) & -0.21 & -1.05 & 1.06 & 0.57 \\
\hline Yearly growth due to Tractor (e) & 1.26 & 0.40 & 0.52 & 0.69 \\
\hline Yearly growth due to Fertilizer (f) & 0.82 & 2.05 & 1.59 & 1.39 \\
\hline Yearly growth due to Livestock (g) & -0.05 & -0.10 & -0.03 & -0.10 \\
\hline Yearly growth due to unaccounted factors $(\mathrm{h})$ & 0.45 & -1.04 & -2.95 & -1.77 \\
\hline Yearly growth due to Total factor productivity change* (i) & -0.65 & 2.61 & 3.23 & 1.81 \\
\hline \multicolumn{5}{|l|}{ Percentage contribution to agricultural growth } \\
\hline Total output growth per year (a) & $100 \%$ & $100 \%$ & $100 \%$ & $100 \%$ \\
\hline Total growth due to factor inputs (b) & $113.88 \%$ & $48.33 \%$ & $92.04 \%$ & $98.41 \%$ \\
\hline Yearly growth due to Land (c) & $-13.51 \%$ & $5.39 \%$ & $3.06 \%$ & $4.14 \%$ \\
\hline Yearly growth due to Labor (d) & $-14.77 \%$ & $-34.76 \%$ & $30.06 \%$ & $21.04 \%$ \\
\hline Yearly growth due to Tractor (e) & $88.10 \%$ & $13.12 \%$ & $14.79 \%$ & $25.44 \%$ \\
\hline Yearly growth due to Fertilizer (f) & $57.40 \%$ & $67.82 \%$ & $44.90 \%$ & $51.31 \%$ \\
\hline Yearly growth due to Livestock $(\mathrm{g})$ & $-3.34 \%$ & $-3.23 \%$ & $-0.77 \%$ & $-3.54 \%$ \\
\hline Yearly growth due to unaccounted factors $(\mathrm{h})$ & $31.23 \%$ & $-34.47 \%$ & $-83.39 \%$ & $-65.35 \%$ \\
\hline Yearly growth due to Total factor productivity change (i) & $-45.11 \%$ & $86.14 \%$ & $91.36 \%$ & $66.95 \%$ \\
\hline
\end{tabular}

Table 5: Northern Africa agricultural growth decomposition by decade

\begin{tabular}{|c|c|c|c|c|}
\hline & $1971-80$ & $1981-90$ & 1991-00 & All (1971-2000) \\
\hline \multicolumn{5}{|l|}{ Source of growth (annual growth rate in percentage) } \\
\hline Total output growth per year & 1.70 & 3.22 & 4.65 & 3.24 \\
\hline Total growth due to factor inputs & 4.04 & 0.71 & 1.15 & 2.17 \\
\hline Yearly growth due to Land & 0.07 & -0.17 & 0.63 & -0.01 \\
\hline Yearly growth due to Labor & 0.93 & -0.30 & -0.41 & 0.31 \\
\hline Yearly growth due to Tractor & 0.91 & -0.32 & -0.17 & 0.28 \\
\hline Yearly growth due to Fertilizer & 1.84 & 1.35 & 0.59 & 1.27 \\
\hline Yearly growth due to Livestock & 0.30 & 0.13 & 0.52 & 0.32 \\
\hline Yearly growth due to unaccounted factors & -2.09 & -0.05 & -0.21 & -1.01 \\
\hline Yearly growth due to Total factor productivity change & -0.25 & 2.56 & 3.71 & 2.08 \\
\hline \multicolumn{5}{|l|}{ Percentage contribution to agricultural growth } \\
\hline Total output growth per year & $100 \%$ & $100 \%$ & $100 \%$ & $100 \%$ \\
\hline Total growth due to factor inputs & $237.53 \%$ & $21.93 \%$ & $24.82 \%$ & $66.92 \%$ \\
\hline Yearly growth due to Land & $3.94 \%$ & $-5.16 \%$ & $13.53 \%$ & $-0.46 \%$ \\
\hline Yearly growth due to Labor & $54.43 \%$ & $-9.18 \%$ & $-8.80 \%$ & $9.61 \%$ \\
\hline Yearly growth due to Tractor & $53.51 \%$ & $-9.87 \%$ & $-3.67 \%$ & $8.58 \%$ \\
\hline Yearly growth due to Fertilizer & $108.10 \%$ & $42.01 \%$ & $12.67 \%$ & $39.27 \%$ \\
\hline Yearly growth due to Livestock & $17.54 \%$ & $4.13 \%$ & $11.09 \%$ & $9.92 \%$ \\
\hline Yearly growth due to unaccounted factors & $-122.64 \%$ & $-1.54 \%$ & $-4.55 \%$ & $-31.18 \%$ \\
\hline Yearly growth due to Total factor productivity change & $-14.88 \%$ & $79.61 \%$ & $79.73 \%$ & $64.27 \%$ \\
\hline
\end{tabular}

Table 6: Western Africa agricultural growth decomposition by decade

\begin{tabular}{|c|c|c|c|c|}
\hline & 1971-80 & $1981-90$ & 1991-00 & All (1971-2000) \\
\hline \multicolumn{5}{|l|}{ Source of growth (annual growth rate in percentage) } \\
\hline Total output growth per year & 1.73 & 3.91 & 4.53 & 3.45 \\
\hline Total growth due to factor inputs & 4.20 & 2.16 & -1.63 & 1.67 \\
\hline Yearly growth due to Land & -1.92 & 0.00 & 2.29 & 0.12 \\
\hline Yearly growth due to Labor & 2.08 & -0.01 & -4.68 & -0.81 \\
\hline Yearly growth due to Tractor & 1.64 & 0.88 & 1.28 & 0.82 \\
\hline Yearly growth due to Fertilizer & 1.86 & 1.33 & 2.20 & 1.70 \\
\hline Yearly growth due to Livestock & 0.55 & -0.04 & -2.72 & -0.17 \\
\hline Yearly growth due to unaccounted factors & -1.01 & -0.38 & 2.71 & 0.30 \\
\hline Yearly growth due to Total factor productivity change & -1.47 & 2.14 & 3.46 & 1.47 \\
\hline \multicolumn{5}{|l|}{ Percentage contribution to agricultural growth } \\
\hline Total output growth per year & $100 \%$ & $100 \%$ & $100 \%$ & $100 \%$ \\
\hline Total growth due to factor inputs & $243.14 \%$ & $55.15 \%$ & $-35.94 \%$ & $48.53 \%$ \\
\hline Yearly growth due to Land & $-111.06 \%$ & $0.09 \%$ & $50.51 \%$ & $3.57 \%$ \\
\hline Yearly growth due to Labor & $120.28 \%$ & $-0.29 \%$ & $-103.27 \%$ & $-23.56 \%$ \\
\hline Yearly growth due to Tractor & $94.90 \%$ & $22.43 \%$ & $28.22 \%$ & $23.87 \%$ \\
\hline Yearly growth due to Fertilizer & $107.76 \%$ & $33.92 \%$ & $48.43 \%$ & $49.45 \%$ \\
\hline Yearly growth due to Livestock & $31.60 \%$ & $-0.97 \%$ & $-59.90 \%$ & $-4.79 \%$ \\
\hline Yearly growth due to unaccounted factors & $-58.31 \%$ & $-9.77 \%$ & $59.70 \%$ & $8.74 \%$ \\
\hline Yearly growth due to Total factor productivity change & $-84.83 \%$ & $54.62 \%$ & $76.24 \%$ & $42.73 \%$ \\
\hline
\end{tabular}


Am. J. Agri. \& Biol., 3(1): 379-388, 2008

Table 7: Eastern Africa agricultural growth decomposition by decade

\begin{tabular}{|c|c|c|c|c|}
\hline & 1971-80 & $1981-90$ & 1991-00 & All (1971-2000) \\
\hline \multicolumn{5}{|l|}{ Source of growth (annual growth rate in percentage) } \\
\hline Total output growth per year & 1.68 & 3.06 & 1.36 & 2.04 \\
\hline Total growth due to factor inputs & -3.68 & -1.32 & 7.88 & 5.53 \\
\hline Yearly growth due to Land & 0.81 & 4.24 & -0.09 & 0.21 \\
\hline Yearly growth due to Labor & -6.68 & -9.56 & 4.83 & 1.75 \\
\hline Yearly growth due to Tractor & 1.58 & -0.13 & 0.29 & 0.82 \\
\hline Yearly growth due to Fertilizer & 0.74 & 4.54 & 3.00 & 3.01 \\
\hline Yearly growth due to Livestock & -0.14 & -0.42 & -0.14 & -0.27 \\
\hline Yearly growth due to unaccounted factors & 3.91 & 0.38 & -9.32 & -6.28 \\
\hline Yearly growth due to Total factor productivity change & 1.45 & 4.00 & 2.79 & 2.79 \\
\hline \multicolumn{5}{|l|}{ Percentage contribution to agricultural growth } \\
\hline Total output growth per year & $100 \%$ & $100 \%$ & $100 \%$ & $100 \%$ \\
\hline Total growth due to factor inputs & $-219.14 \%$ & $-43.31 \%$ & $581.29 \%$ & $270.58 \%$ \\
\hline Yearly growth due to Land & $48.45 \%$ & $138.69 \%$ & $-6.98 \%$ & $10.28 \%$ \\
\hline Yearly growth due to Labor & $-397.24 \%$ & $-312.72 \%$ & $356.34 \%$ & $85.85 \%$ \\
\hline Yearly growth due to Tractor & $94.22 \%$ & $-4.15 \%$ & $21.37 \%$ & $40.32 \%$ \\
\hline Yearly growth due to Fertilizer & $43.98 \%$ & $148.45 \%$ & $220.93 \%$ & $147.57 \%$ \\
\hline Yearly growth due to Livestock & $-8.51 \%$ & $-13.89 \%$ & $-10.31 \%$ & $-13.44 \%$ \\
\hline Yearly growth due to unaccounted factors & $232.78 \%$ & $12.53 \%$ & $-687.09 \%$ & $-307.20 \%$ \\
\hline Yearly growth due to Total factor productivity change & $86.32 \%$ & $130.80 \%$ & $205.83 \%$ & $136.61 \%$ \\
\hline
\end{tabular}

Table 8: Southern Africa agricultural growth decomposition by decade

\begin{tabular}{|c|c|c|c|c|}
\hline & 1971-80 & 1981-90 & 1991-00 & All (1971-2000) \\
\hline \multicolumn{5}{|l|}{ Source of growth (annual growth rate in percentage) } \\
\hline Total output growth per year & 1.25 & 1.79 & 4.44 & 2.53 \\
\hline Total growth due to factor inputs & -1.64 & 4.98 & 3.59 & 4.47 \\
\hline Yearly growth due to Land & 0.08 & 0.04 & 0.17 & -0.07 \\
\hline Yearly growth due to Labor & -1.41 & 4.62 & 2.02 & 2.92 \\
\hline Yearly growth due to Tractor & -1.59 & -0.31 & 0.43 & 0.27 \\
\hline Yearly growth due to Fertilizer & 0.89 & 0.10 & 0.96 & 1.15 \\
\hline Yearly growth due to Livestock & 0.39 & 0.53 & 0.01 & 0.20 \\
\hline Yearly growth due to unaccounted factors & 4.56 & -5.68 & -1.74 & -3.16 \\
\hline Yearly growth due to Total factor productivity change & -1.68 & 2.49 & 2.59 & 1.23 \\
\hline \multicolumn{5}{|l|}{ Percentage contribution to agricultural growth } \\
\hline Total output growth per year & $100 \%$ & $100 \%$ & $100 \%$ & $100 \%$ \\
\hline Total growth due to factor inputs & $-131.81 \%$ & $278.43 \%$ & $80.86 \%$ & $176.27 \%$ \\
\hline Yearly growth due to Land & $6.62 \%$ & $1.99 \%$ & $3.80 \%$ & $-2.79 \%$ \\
\hline Yearly growth due to Labor & $-113.18 \%$ & $258.44 \%$ & $45.43 \%$ & $115.44 \%$ \\
\hline Yearly growth due to Tractor & $-127.92 \%$ & $-17.12 \%$ & $9.61 \%$ & $10.59 \%$ \\
\hline Yearly growth due to Fertilizer & $71.10 \%$ & $5.39 \%$ & $21.69 \%$ & $45.23 \%$ \\
\hline Yearly growth due to Livestock & $31.64 \%$ & $29.72 \%$ & $0.31 \%$ & $7.80 \%$ \\
\hline Yearly growth due to unaccounted factors & $366.59 \%$ & $-317.61 \%$ & $-39.23 \%$ & $-124.87 \%$ \\
\hline Yearly growth due to Total factor productivity change & $-134.70 \%$ & $139.18 \%$ & $58.37 \%$ & $48.60 \%$ \\
\hline
\end{tabular}

Table 9: Central Africa agricultural growth decomposition by decade

\begin{tabular}{|c|c|c|c|c|}
\hline & 1971-80 & $1981-90$ & 1991-00 & All (1971-2000) \\
\hline \multicolumn{5}{|l|}{ Source of growth (annual growth rate in percentage) } \\
\hline Total output growth per year & 0.27 & 1.92 & 2.72 & 1.68 \\
\hline Total growth due to factor inputs & 4.67 & 9.50 & -0.62 & 4.41 \\
\hline Yearly growth due to Land & 0.68 & 0.45 & 0.00 & 0.11 \\
\hline Yearly growth due to Labor & 0.96 & 7.58 & -1.77 & 3.09 \\
\hline Yearly growth due to Tractor & 2.54 & 0.12 & 0.02 & 0.65 \\
\hline Yearly growth due to Fertilizer & 0.97 & 1.67 & 0.97 & 0.76 \\
\hline Yearly growth due to Livestock & -0.48 & -0.33 & 0.16 & -0.21 \\
\hline Yearly growth due to unaccounted factors & -2.54 & -9.20 & 0.04 & -3.85 \\
\hline Yearly growth due to Total factor productivity change & -1.87 & 1.63 & 3.30 & 1.12 \\
\hline \multicolumn{5}{|l|}{ Percentage contribution to agricultural growth } \\
\hline Total output growth per year & $100 \%$ & $100 \%$ & $100 \%$ & $100 \%$ \\
\hline Total growth due to factor inputs & $1762.64 \%$ & $494.02 \%$ & $-22.75 \%$ & $262.20 \%$ \\
\hline Yearly growth due to Land & $254.96 \%$ & $23.41 \%$ & $0.09 \%$ & $6.76 \%$ \\
\hline Yearly growth due to Labor & $362.41 \%$ & $394.13 \%$ & $-65.05 \%$ & $183.79 \%$ \\
\hline Yearly growth due to Tractor & $959.88 \%$ & $6.14 \%$ & $0.72 \%$ & $38.82 \%$ \\
\hline Yearly growth due to Fertilizer & $367.18 \%$ & $87.13 \%$ & $35.63 \%$ & $45.10 \%$ \\
\hline Yearly growth due to Livestock & $-181.76 \%$ & $-16.93 \%$ & $5.84 \%$ & $-12.33 \%$ \\
\hline Yearly growth due to unaccounted factors & $-956.98 \%$ & $-478.56 \%$ & $1.39 \%$ & $-228.64 \%$ \\
\hline Yearly growth due to Total factor productivity change & $-705.28 \%$ & $84.55 \%$ & $121.35 \%$ & $66.43 \%$ \\
\hline
\end{tabular}


Am. J. Agri. \& Biol., 3(1): 379-388, 2008

Table 10: Source of growth in African agricultural sector by colonial heritage, 1971-2000

\begin{tabular}{|c|c|c|}
\hline & $\begin{array}{l}\text { Former French } \\
\text { colony }\end{array}$ & $\begin{array}{l}\text { Former British } \\
\text { colony }\end{array}$ \\
\hline \multicolumn{3}{|c|}{ Source of growth (annual growth rate in percentage) } \\
\hline Total output growth per year & 2.80 & 3.02 \\
\hline Total growth due to factor inputs & 3.34 & 0.80 \\
\hline Yearly growth due to Land & 0.05 & 0.30 \\
\hline Yearly growth due to Labor & 0.80 & -1.38 \\
\hline Yearly growth due to Tractor & 0.93 & 0.21 \\
\hline Yearly growth due to Fertilizer & 1.55 & 2.08 \\
\hline Yearly growth due to Livestock & 0.02 & -0.41 \\
\hline $\begin{array}{l}\text { Yearly growth due to } \\
\text { unaccounted factors }\end{array}$ & -2.13 & -0.02 \\
\hline $\begin{array}{l}\text { Yearly growth due to Total factor } \\
\text { productivity change }\end{array}$ & 1.58 & 2.24 \\
\hline \multicolumn{3}{|c|}{ Percentage contribution to agricultural growth } \\
\hline Total output growth per year & $100 \%$ & $100 \%$ \\
\hline Total growth due to factor inputs & $119.57 \%$ & $26.48 \%$ \\
\hline Yearly growth due to Land & $1.66 \%$ & $9.93 \%$ \\
\hline Yearly growth due to Labor & $28.47 \%$ & $-45.66 \%$ \\
\hline Yearly growth due to Tractor & $33.19 \%$ & $7.01 \%$ \\
\hline Yearly growth due to Fertilizer & $55.51 \%$ & $68.89 \%$ \\
\hline Yearly growth due to Livestock & $0.74 \%$ & $-13.67 \%$ \\
\hline $\begin{array}{l}\text { Yearly growth due to } \\
\text { unaccounted factors }\end{array}$ & $-76.08 \%$ & $-0.56 \%$ \\
\hline $\begin{array}{l}\text { Yearly growth due to Total } \\
\text { factor productivity change }\end{array}$ & $56.50 \%$ & $74.05 \%$ \\
\hline
\end{tabular}

Table 11: Source of growth in African agricultural sector by agroecological regions, 1971-2000

\begin{tabular}{lcl}
\hline & $\begin{array}{l}\text { Sahelian } \\
\text { Countries }\end{array}$ & $\begin{array}{l}\text { Forest } \\
\text { countries }\end{array}$ \\
\hline $\begin{array}{l}\text { Source of growth (annual growth rate in percentage) } \\
\text { Total output growth per year }\end{array}$ & 3.32 & 2.32 \\
Total growth due to factor inputs & 1.48 & 3.31 \\
Yearly growth due to Land & 0.02 & 0.20 \\
Yearly growth due to Labor & -0.35 & 1.19 \\
Yearly growth due to Tractor & 0.65 & 0.67 \\
Yearly growth due to Fertilizer & 1.11 & 1.50 \\
Yearly growth due to Livestock & 0.04 & -0.24 \\
Yearly growth due to & 0.04 & -2.80 \\
unaccounted factors & & \\
Yearly growth due to Total factor & 1.81 & 1.82 \\
productivity change & & \\
Percentage contribution to agricultural growth & \\
Total output growth per year & $100 \%$ & $100 \%$ \\
Total growth due to factor inputs & $44.40 \%$ & $142.37 \%$ \\
Yearly growth due to Land & $0.69 \%$ & $8.52 \%$ \\
Yearly growth due to Labor & $-10.39 \%$ & $51.17 \%$ \\
Yearly growth due to Tractor & $19.50 \%$ & $28.75 \%$ \\
\hline
\end{tabular}

agricultural production included livestock as independent variable ${ }^{[18,19,8,10]}$. The contribution to agricultural output growth of livestock is globally negative. This contribution is the highest (and positive) in North and southern Africa where it accounts respectively for 8 and 10 percent of total agricultural output growth and the lowest (and negative) in West, East and Central Africa where it explains -5, -13 and -12 percent of total output growth.
We further investigated the impact of colonial inheritance and agro-climatic conditions on growth accounting parameters. Table 10 and 11 show comparative growth accounting for French and English countries and for forest and sahelian countries. Some tendencies can be observed from these results:

- The contribution of physical inputs, particularly labor and tractor has been highest in French speaking countries, while TFP growth was more important in English countries than in French countries. Unaccounted factors (agro-climatic shocks, political instability...) have been a major constraint for agricultural production growth in French speaking countries, whereas in English countries, these factors have had no significant effects. We previously found that East Africa was the region where unaccounted factors had the most negative effect on growth. This can be explained by the political instability that Rwanda and Burundi (which are also French speaking countries) recently went through

- When comparing sahelian vs forest countries (Table 11), it appears that agricultural growth attributable to factor accumulation was higher than TFP contribution in forest countries, while in sahelian countries, TFP contribute more than physical factor to agricultural growth. Unaccounted factors also impede agricultural growth in forest countries

\section{CONCLUSION}

Thus, the issue of agricultural growth in Africa, its determinants, policies that affect it and prospects, has tremendous implications. Empirical studies ${ }^{[20,21]}$ clearly confirmed that increased agricultural productivity and growth is the cornerstone of the millennium development goals (MDGs) in Africa. The consensus in international economic development circles is that Africa is still far from reaching the targeted goal of an annual growth rate above $7 \%$ a year required to achieve economic convergence with other developing countries and to maintain a similar quality of life.

This study has investigated the source of growth in the agricultural sector in Africa. The study used the broader framework provided by empirical growth literature and recent development in TFP measurement to search for fundamental determinants of growth in African agriculture. The following findings emerged from the study:

- The result show an average annual growth in total factor productivity of $0.2 \%$, mainly attributable to the 
technological change (or frontier shift) growth of $0.4 \%$. Two tendencies have been observed during the period. The rate of technological change and total factor productivity change was globally negative during the 1970s and turned positive during the 1980s and 1990s. These findings are consistent with past studies ${ }^{[15,10,5]}$

- The technical efficiency change (managerial ability) has experienced an overall negative evolution over the 30 years. This suggests that farmers have been less and less able to fully exploit the full potentiality of new technologies. This result is quite different from Coelli and $\mathrm{Rao}^{[15,5]}$ who found a positive (0.6 and 0.8 respectively) average efficiency change, although for a different time intervals

- Our results share the view that factor accumulation accounts for a large share of agricultural output growth. The contribution of traditional factor inputs to overall agricultural growth has been on average larger than that of TFP

- We also highlighted the fact that unpredicted factors such as agro-climatic shocks, institutions and political instability, also contributed importantly to agricultural output growth in Africa

- In all African regions, fertilizer has been the most important physical inputs contributor to agricultural growth. Suggesting that fertilizer had a good foundation, on which one can build strong equitable agricultural growth in Africa

- We found that agricultural growth contributors across countries and regions vary greatly, reflecting different country conditions, institutions and politico-historical factors. In particular, colonial heritage and agro-ecological condition of countries was found to have an influence on the source of agricultural growth

These results have important implications for policy targeting. The negative evolution of the efficiency change component suggests that farmers are not making the best use of the existing technologies, which are mostly imported technologies. This point out the constraint imposes by the absorption of foreign technologies in the achievement of high levels of total factor productivity. This highlights the limits of the diffusion of new technologies without accompanying these with building the capacity of farmers to enable them to fully exploit the potentiality of these technologies. To foster TFP growth, there is a need for sustained improvements in farmers' performance, which will require a more active role for the public sector and international agencies in research and extension activities in collaboration with farmers to raise human capital accumulation. A promising possibility may be to train farmers in production programs for them to learn more on crop

One main contribution and new findings in this study is the quantification of the contribution of different inputs in the agricultural growth. One general conclusion is that the role and contribution of different inputs differ substantially between regions and countries. These regional differences show types and the extent of interventions needed to be put in place in each region for enhancing the agricultural growth of African agriculture. For some group of countries such as forest and French speaking countries, the agricultural growth attributable to factors such as labor, tractor and fertilizer was positive and high, while the contribution of livestock has been highly negative in English speaking and forest countries. In forest countries, livestock pest related problems might have played a negative role and pulled back the livestock sub-sector. Future strategies should be conscious of such constraints. The contribution of land also appears to be lower for Sahelian and French speaking countries. These results should be taken into account to build strategies to overcome the problem of agricultural growth in Africa. Efforts are needed not only from within the countries and regions, but also from the international community to ensure that the right mixture of policies is put in place to promote and sustain agricultural production in Africa. However, over time, the sources of agricultural growth may shift and even change signs as economies and policies evolve. A country's broader historical experiences and institutional evolution need to be constantly taken into account.

\section{REFERENCES}

1. Lele, Uma, 1991. Aid to African Agriculture: Lessons from Two Decades of Donors' Experience. Baltimore: Johns Hopkins University Press.

2. O'Connell, S.A. and B.J. Ndulu, 2000. Africa growth experience: A focus on sources of growth. AERC/Havard Conference on Africa Economic Growth, Cambridge, MA, March 26-27, 1999.

3. Downes, A.S., 2001. Economic growth in a small developing country: The case of Barbados. GDN/LACEA project on economic growth in Latin America and the Caribbean. Global Development Network.

4. Solow Robert, 1956. A contribution to the theory of economic growth. Q. J. Econ., 70 (February): 65-94. 
5. Rao, D.S.P. and T.J. Coelli, 1998. Catch-Up and Convergence in Global Agricultural Productivity 1980-1995. CEPA Working Paper No 4/98.

6. Rao, D.S.P., 1993. Inter-country comparisons of agricultural output and productivity. Social and Economic Development Paper, No. 156 FAO.

7. Hayami, Y. and V.W. Ruttan, 1970. Agricultural productivity differences among countries. Am. Econo. Rev., 60: 895-911.

8. Rao, D.S.P., J. O'donnell and G.E. Battese, 2003. Metafrontier functions for the study of interregional productivity differences. Centre for Efficiency and Productivity Analysis Working Paper 1.

9. Hayami, Y. and V.W. Ruttan, 1971. Agricultural Development: International Perspective. Baltimore: John Hopkins University Press.

10. Fulginiti, E.L., P.K. Perrin and Y. Bingxin, 2004. Institutions and Agricultural productivity in SubSaharan Africa. Agric. Econ., 31 (2004) 169-180.

11. Limam, Y.R. and S.M. Miller, 2004. Explaining economic growth: Factor accumulation, total factor productivity growth and production efficiency improvement. Department of economic working paper series 2004-20. Connecticut University.

12. Fare, R.S., S. Grosskopf and C.A.K. Lovell, 1994. Production Frontière. Cambridge University Press, Cambridge, UK.

13. Coelli, T.J., D.S.P. Rao and G. Battese, 1998. Introduction to Efficiency and Productivity Analysis. Kluver Academic Publisher, Boston.
14. Nkamleu, G.B., 2004b. Productivity growth, technical progress and efficiency change in African agriculture. Afr. Dev. Rev. 16 (1): 203-222.

15. Coelli, Tim J. and D.S.P. Rao, 2005. Total factor productivity growth in Agriculture: A Malmquist Index Analysis of 93 Countries, 1980-2000. Agricultural Economics 32 (s1), 115-134, Blackwell publishing Ltd.

16. Benhabib, J. and M.M. Spiegel, 1994. The role of human capital in economic development: Evidence from aggregate cross-country data. J. Monetary Econ., 34: 363-390.

17. Busari, D.T., A.A. Amin and T. Ntilivamunda, 2005. Modeling total factor productivity in African economies. Tenth Annual Conference on Econometric Modeling in Africa, 6-8 July 2005, Nairobi Kenya.

18. Fulginiti, E.L. and R.K. Perrin, 1997. LDC agriculture: Nonparametric malmquist productivity index. J. Dev. Econ., 53: 373-390.

19. Kudaligama, V.P. and J.F. Yanagida, 2000. A comparison of intercountry agricultural production functions: A frontier function approach. J. Econ. Dev., 25 (1): 57-74.

20. Interacademy council, 2004. Realizing the promise and potential of African agriculture: Science and technology strategies for improving agricultural productivity and food security in Africa. Amsterdam, the Netherlands.

21. World Bank, 2005. Pro-poor growth in the 1990s: Lessons and insights from 14 countries. Washington DC, USA. 